\title{
Kald krig i kommentarfeltet? Historien om Frode Berg på russisk internett
}

\author{
Johanne Kalsaas* \\ Stipendiat, russisk media og kommunikasjon, Institutt for fremmedspråk, \\ Universitetet i Bergen, Norge
}

\begin{abstract}
Cold War in the Comments Section? The Story of Frode Berg on the Russian-language Internet

The article explores how the Russo-Norwegian espionage debacle involving former border inspector Frode Berg was collectively and fragmentarily narrated by Russian online commenters. Through a digital ethnographic case study of user-driven segments on the Russian-language Internet (RuNet) - notably Live fournal and RT comment sections - this article shows how online narratives about the case involved participatory production by heterogeneous, polyphonous constellations of users. Analysing Russian online comments as network narratives, the article examines how Norway (as well as NATO and the West more broadly) has been construed on $R u N e t$, where propaganda is ubiquitous, and where trolls, bots, vatniki and 'everyone else' continuously clash. Commenters' discussions of the Berg case reflect Kremlin-controlled narratives of Norway as an ambiguous actor associated with a high degree of ambivalence, but network narratives also reveal tensions, inconsistencies and contestation of the Russian antagonist discourse on Norway. More broadly, the study highlights how interactive digital narrative can serve to expand our understanding not only of Russia's relationship with Norway, but also of Russian informational activities as such.
\end{abstract}

Keywords: digital ethnography, network narratives, online comments, Russian-language Internet (RuNet)

«Redd Frodo!'» er kampropet i kommentarfeltet under et populært innlegg (colonelcassad, 2018b) om Frode Berg-saken i det russiske segmentet av Live fournal stadig en av landets viktigste digitale plattformer (Deloitte, 2020, s. 26). Sammen med et bilde av den modige, lille hobbiten som står opp mot mørkets hersker i Tolkiens epos, leser kommentatoren ved første øyekast spionskandalen som noe i

\footnotetext{
${ }^{1}$ Alle oversettelser fra russisk til norsk er gjort av forfatteren, med mindre annet er oppgitt. Tegnsetting, emoji-bruk og eventuelle skrivefeil er forsøkt bevart i oversettelsene, for å gi et mest mulig autentisk bilde av kommentarene. Som et tiltak mot personvernrisiko er kommentarene anonymisert og oppgitt i oversettelse.
}

\footnotetext{
^Kontaktinformasjon: Johanne Kalsaas, e-post: johanne.kalsaas@uib.no 
nærheten av en martyrlegende: En reinhjertet, blåøyd nordmann sendes på edelt oppdrag til Mordor-Russland, men blir angrepet av de fryktinngytende skyggeskapningene fra FSB. I en klassisk dramatisering av kampen mellom det gode og det onde blir den usannsynlige helten Frode - som Frodo - fanget i Sauron-Putins klør. Den allegoriske leken i kommentarfeltet er imidlertid stenket i satire: Appellen om å redde Frodo/Frode spiller inn i den kollektive digitale harselasen med en karikert vestlig - og russisk opposisjonell - diskurs om spionskandalen mellom Norge og Russland. Offerfortellingen om nordmannen i russiske lenker er, i ZjeZjeistens ${ }^{2}$ øyne, minst like virkelighetsfjern som eventyret om hobbiten som redder Midgard.

Sarkastiske allusjoner til Ringenes Herres fantasiunivers var et tilbakevendende element i russiske nettdebattanters lesning av Frode Berg-saken (jf. kommentarene under @dw_russian, 2019; InoTV, 2018a; Novaja Gazeta, 2019). Allusjonene utfoldet seg i kommentarfeltene under radikalt forskjellig innhold; på tvers av Russlands digitale medialandskap; fra brukere som ikke kunne knyttes sammen på noen måte. ${ }^{3}$ For å forstå det tilsynelatende usammenhengende satirespillet rundt spionsaken argumenterer jeg i denne artikkelen for at kommentarene bør leses som interaktive digitale narrativ (IDN) og nettverksfortellinger (Koenitz et al., 2015; J. Walker, 2004) - fragmenterte, foranderlige historier med fordelt forfatterskap. Disse historiene fortelles i et digitalt landskap der propaganda har blitt en deltageraktivitet og organiserte påvirkningskampanjer smelter sammen med organisk innhold (Asmolov, 2019; Rid, 2020). Gjennom en digitaletnografisk studie av brukerdebatt om spion-skandalen på bloggsamfunnet Live fournal og nyhetsplattformen InoTV vil jeg i denne artikkelen utforske følgende spørsmål: (1) Hvilke norgesbilder kommer til uttrykk i russiske nettverksfortellinger om Berg-saken? (2) Hvordan forholder de digitale historiene seg til offisielle russiske norgesnarrativ? ${ }^{4} \mathrm{Og}$, mer overgripende: (3) Hva kan nettverksfortellingene si oss om Norges rolle i Russlands narrative offensiv (Rogers et al., 2017) mot Vesten?

Få hendelser i nyere norsk-russisk historie har vært mer omtalt enn Frode Bergsaken. ${ }^{5}$ Likevel fremstår flere aspekter ved spionskandalen nærmest uutforskede. Særlig gjelder dette russiske forståelser av hendelsen. Der norsk pressedekning har fått kritikk for unyanserte offerfortellinger (Gerhardsen, 2019) har heller ikke rekken av bokutgivelser ${ }^{6}$ nødvendigvis lyktes i å belyse sakens betydning for norsk-russiske relasjoner (Rowe, 2019; Østbø, 2021). Akademia har på sin side i liten grad bidratt

\footnotetext{
${ }^{2}$ Live fournal-bruker. Avledet fra initialene i plattformens russiske tittel, Zjivoj Zjurnal.

${ }^{3}$ Ingen brukernavn, profilbilder eller (åpent tilgjengelige) metadata til felles.

${ }^{4}$ Offisielle narrativ blir her knyttet til Russlands styresmakter, og satt i sammenheng med strategiske dokumenter, lovverk og offentlige uttalelser fra russiske myndigheter.

${ }^{5} 6$. mai 2021 gir søkeordet «Frode Berg» over 5000 unike treff i Google Nyheter. Søkeresultater i Google er til en viss grad brukerspesifikke og nødvendigvis filtrert gjennom mer eller mindre ugjennomsiktige algoritmer, men kan likevel illustrere hvor stor resonans en sak har hatt i nyhetsbildet. ${ }^{6}$ En god nordmann av Trine Hamran (2019), En uvanlig spion av Øystein Bogen (2019), og I grenseland av Morten Jentoft (2020). Felles for utgivelsene er et fokus på personen Frode Berg.
} 
til økt forståelse: Berg-saken har per juli 2021 ikke vært tema for vitenskapelig publisering verken i Russland, Norge eller Norden for øvrig. ${ }^{7}$

Forskningsmangelen rundt spionskandalen overlappes av kunnskapshullet rundt russiske digitale narrativ om Norge. Parallelt med at narrativkrigen på nett blir identifisert som en av Norges største beredskapsutfordringer og et felt som trenger større forskningsinnsats (Diesen, 2018; Strand \& Hagen, 2015), figurerer russiske nettverksoperasjoner sentralt i norske trusselvurderinger (Bergh, 2020; Politiets sikkerhetstjeneste, 2021). Likevel finnes det ingen uavhengig studie av norgesfortellinger i russiske sosiale nettverk. ${ }^{8}$ Selv om interessen for russisk informasjonsaktivitet på nett har eksplodert siden påvirkningsoperasjonen mot USAs presidentvalg i 2016, er det fortsatt aktiviteten $\mathrm{i}$ andre lands informasjonssfærer som får størst forskningsfokus (Aro, 2016; Boatwright et al., 2018; Golovchenko, 2020; Helmus et al., 2018; Zannettou et al., 2019). Kommunikasjonsdynamikken innad i det russiske segmentet av internett (RuNet) og dennes evne til å belyse Russlands internasionale informasjonsoffensiv har i mindre grad blitt utforsket (jf. Kurowska \& Reshetnikov, 2018; Vesselkov et al., 2020). Ved å bruke Berg-saken som utgangspunkt for å undersøke norgesfortellinger på et RuNet som i økende grad er et våpen i - og mål for Russlands informasjonskrig (Maréchal, 2017), kaster denne artikkelen dermed lys på en skyggelagt del av Russlands forhold til Norge.

Artikkelen begynner med et sammendrag av Berg-saken og reaksjonen fra russiske myndigheter. Jeg fortsetter ved å redegiøre for artikkelens empiriske grunnlag, forskningsdesign og teoretiske rammeverk. Som kontekst for analysen av russiske nettverksfortellinger skisseres noen karakteristiske trekk ved russisk internettkommunikasjon, særlig den digitale propagandaens rolle, før jeg gir en oversikt over etablerte russiske norgesnarrativ. Etter å ha presentert funnene mine diskuterer jeg avslutningsvis hvordan de digitale historiene om Berg-saken kan belyse Russlands informasjonsoffensiv - og Norges plass i denne.

\section{Frode Berg-sakens realiteter og (vakuumet av) russiske offisielle narrativ}

I desember 2017 ble en pensjonert grenseinspektør for den norsk-russiske grensen og mangeårig forkjemper for samarbeid mellom landene, Frode Berg, arrestert av FSB i Moskva. Berg ble anklaget for å ha samlet hemmelig informasjon om Russlands marine på vegne av norske og amerikanske etterretningstjenester. Saken

\footnotetext{
${ }^{7}$ Forfatteren bekjent. Et nevneverdig unntak er en masteroppgave i fred og konfliktstudier ved Universitetet i Oslo av Oliveira de Almeida Toscano, L. (2019). Kirkenes: a case for borderland Norwegians? An analysis of the discourses and practices towards Russia following the Storskog and Frode Berg cases.

${ }^{8}$ Der Norge har vært inkludert i forskning på russiske digitale narrativ, har dette vært som del av den nordisk-baltiske gruppen. Videre har disse studiene i sin tilnærming til digitale medier fokusert på redaksjonsstyrt heller enn brukerskapt innhold.
} 
skapte harme og mistro i Bergs hjemby Kirkenes, der anklagen tidlig ble sett som absurd (Furuly, 2017). Berg vedkjente imidlertid seinere at han hadde vært på kureroppdrag for E-tjenesten da han ble pågrepet, og mente at han hadde blitt utnyttet. Norske myndigheter svarte på påstanden med taushet (Skårdalsmo, 2019). I april 2019 ble Berg dømt til 14 års fengsel. Han ble i november samme år benådet av russiske myndigheter og overført til Litauen gjennom en spionutvekslingsavtale der både litauisk, norsk og amerikansk etterretning var involvert (Eisenträger, 2020). Siden gjenkomsten til Norge har Berg rettet skarp kritikk mot norske myndigheter. I 2020 fikk han 4,3 millioner kroner i erstatning av staten, som avviste at erstatningen var en innrømmelse av ansvar for hendelsen (Krüger et al., 2020). Stortingets kontrollutvalg for etterretnings-, overvåknings- og sikkerhetstjeneste (EOS-utvalget) konkluderte i 2021 i en rapport at E-tjenesten hadde begått flere alvorlige feil i Bergsaken. Hemmeligholdet rundt rapporten - og Berg-saken for øvrig - vakte opphetet debatt om de hemmelige tjenestene, offentlighetsprinsippet og det norske demokratiet mer overordnet (Persen, 2021).

På russisk side bar den historiske spionanklagen mot en nordmann preg av et narrativunderskudd på offisielt hold. FSB, som pågrep Berg, kom aldri med noen offentlig uttalelse - et brudd med praksis fra tidligere pågripelser av nordisk-baltiske borgere (Interfax, 2015, 2016). Heller ingen andre statlige organer ytret seg om fengslingen av Berg, ${ }^{9}$ og informasjon rundt den hemmeligstemplede straffesaken var sparsom. ${ }^{10}$ I den grad tausheten ble brutt, var det giennom kategorisk avvisning av at spionsaken hadde noen betydning for det norsk-russisk forholdet. Uttalelsen fra pressetalskvinne i russisk UD, Maria Zakharova (2017), er illustrerende: «Dette er ikke den hendelsen (ne tot slutsjaj) som kan kategoriseres slik. Vårt forhold til Norge utvikler seg på en rekke ulike områder. Dette er sånt som skjer (...)». Zakharovas bagatellisering av spionsaken som et hendelig uhell $\mathrm{i}$ et ellers konstruktivt norskrussisk forhold er likevel først og fremst betydningsfull i det den ikke nevner: At spionskandalen ikke er "den hendelsen» som skader kontakten med Norge, antyder at en annen hendelse har gjort det. Det trengs ingen videre fantasi for å forstå at Zakharova implisitt fordømmer Norges angivelig anti-russiske linje i kjølvannet av Ukraina-konflikten (se også Zakharova, 2020).

Tvetydigheten i Zakharovas uttalelse, der spionsaken avfeies som betydningsløs mens det alluderes til alvoret i Norges handlinger på andre områder, ble forsterket under utenriksminister Lavrovs norgesbesøk $\mathrm{i}$ anledning frigjøringsjubileet $\mathrm{i}$ Kirkenes i 2019. Lavrov avviste at «'spiontemaet" på [noen] måte påvirker forholdet mellom de to landene" (Lavrov sitert iTASS, 2019). Parallelt kom han med en patostung fordømmelse av norsk russlandspolitikk, der han anklaget Norge for å forråde landenes felles fortid etter annektering av Krim i 2014 (Lavrov, 2019). Ved å forlate sin «basepolitikk» og akseptere militær opptrapping i nordområdene fra et ekspansivt

\footnotetext{
${ }^{9}$ Meldingen om anklagene mot Berg kom først fra den lokale Lefortovo-retten i Moskva.

${ }^{10}$ Tausheten på offisielt hold var, som vist, i høyeste grad også speilet i Norge.
} 
NATO med USA i spissen, setter Norge ikke bare forholdet til Russland, men hele grensesonen i fare. Lavrov skildrer en norsk suverenitet i krise: Landet svikter sine nasjonale interesser og politiske prinsipper til fordel for den amerikanskledete offensiven mot Russland.

Fra Kremls side ble Berg-saken dermed formidlet som en uheldig, men uviktig hendelse der Russland storsinnet vendte det andre kinnet til. Samtidig fikk saken funksjon som springbrett for en annen, mer alvorsladet fortelling om det norskrussiske forholdet: Norge forsaker århundrer med fredelig samarbeid ved å gi NATO fritt spillerom på sitt territorium. For russiske myndigheter knyttes den overgripende utfordringen i forholdet til Norge ikke til etterretningsspillet i grensesonen, men til Ukraina-spørsmålet.

\section{Narrativ i nettverksperspektiv: Teori, metode og empirisk grunnlag}

Narrativ teori står sentralt i faglitteratur om Russlands kommunikasjonsoffensiv mot Norden (se bl.a. Cepurītis et al., 2020; Deverell et al., 2021). Likevel har litteraturen i liten grad belyst hvordan narrativ påvirkes av nettverksteknologi. Hos StratCom, en sentral aktør på dette forskningsfeltet, knyttes russisk narrativ makt fremfor alt til en stringent fortellerlogikk der protagonisten, antagonisten og konflikten mellom dem formidles på en sammenhengende og konsekvent måte (Cepurītis et al., 2020, s. 13-14). Her blir narrativ forstått som noe enhetlig og grunnleggende kontrollerbart. Denne forståelsen passer dårlig med realiteten i det sosiale medielandskapet, og med en gryende konsensus om at digital propaganda er et underkoordinert fenomen der heterogene grupper sprer et mangfold av ofte motstridende meldinger (Rid, 2020; Starbird, 2019; Starbird et al., 2019).

I denne sammenhengen fremstår teorier om interaktivt digitalt narrativ (IDN) mer fruktbare. Basert på premisset om at digitale medier radikalt endrer narrativets funksjon og form, mener IDN-teoretikere at nettverksteknologi kan giøre publikum til aktive medforfattere av en fortelling (Koenitz et al., 2015). Digitale narrativ blir altså ikke bare konsumert, men produsert, av sitt publikum. I forlengelsen av dette ser jeg begrepet nettverksfortelling som særlig nyttig. Jill Walker (2004, s. 1) kaller dette «stories that can't be experienced in a single session or in a single space». Slike fortellinger er grunnleggende fragmenterte, ikke-lineære, fortalt i og av nettverk (se også Page et al., 2013; Sadler, 2017). ${ }^{11}$ De er spredt ut i tid og rom, men også i forfatterskap. Ingen enkeltforteller kontrollerer fortellingen, heller ikke hvor, når eller av hvem den blir (med-)fortalt (Walker, 2004, s. 5). Fortellingsuniverset overskrider dermed kjernehistorien: Opprinnelig innhold deles og diskuteres på tvers av digitale

\footnotetext{
${ }^{11}$ Walker (2004) bruker begrepet distributed narrative. Page et al. (2013) bruker begrepet networked narrative, som nok har fått større fotfeste i litteraturen på digital fortellerdynamikk siden Walkers nybrottsarbeid. Jeg bruker selv nettverksfortelling i denne artikkelen.
} 
arenaer, danner grunnlag for ny innholdsproduksjon, som etter tur trigger nye former for deltagelse.

Mitt forsøk på å operasjonalisere begrepet nettverksfortelling har munnet ut i en flerstedet, diskursorientert digital etnografi etter Marcus' (1995, s. 109) prinsipp om å «følge etter en historie» ${ }^{12}$ som strekker seg over ulike steder, sammenhenger og subjekter (se også Airoldi, 2018). Målet med denne typen feltarbeid er å utforske forbindelser mellom et større meningsskapende system (som et digitalt fortellerunivers) og spesifikke situasjoner (som et kommentarfelt). Mer konkret handler denne metoden om finne fruktbare «sporingsstrategier» gjennom en ofte overveldende mengde materiale. Min strategi var som følger: Først kartla jeg hvor Berg-saken ble omtalt på RuNet mellom 5. desember 2017 og 30. november 2019 ved hjelp av Yandex' søkemotorer for nyheter og sosiale nettverk. ${ }^{13}$ Jeg avgrenset til treff med interaktive elementer, særlig kommentarvirksomhet. Innenfor dette utvalget identifiserte jeg et nettverk av redaksjons- og brukerstyrte digitale medier som publiserte aktivt om Berg-saken, til stort brukerengasjement. Jeg observerte kommentaraktiviteten i dette medienettverket, og hvilke norgesbilder den reflekterte. Gjennom observasjonen identifiserte jeg to særlig aktive «fortellernettverk»: Et knyttet til $R T \mathrm{~s}^{14}$ russiskspråklige plattform for utenlandske nyheter, InoTV, et annet knyttet til en av de største bloggene på Live fournal, Colonel Cassad. Jeg gjennomførte en eksempelstudie av kommentarer på de fire mest populære publikasjonene om Berg-saken fra hvert av de to nettverkene. ${ }^{15}$ Analysen i denne artikkelen er basert på i overkant av 700 kommentarer fra disse åtte kommentarfeltene (se figur 1). Brukerdebatten om spionskandalen i disse svært ulike digitale kontekstene - en kringkaster med tette bånd til regimet og en bloggplattform kjent for uavhengig meningsutveksling ${ }^{16}$ - kaster lys på det større fortelleruniverset om Berg-saken på RuNet. Eksempelstudien av RT og Live fournal speiler også den sentrale posisjonen de to mediene har i tidligere forskning på Russlands informasjonslandskap (jf. Sylvia IV, 2020; Yablokov \& Chatterje-Doody, 2021) og giør at artikkelen kan leses inn i en større faglig sammenheng.

Tilnærmingen beskrevet ovenfor er ikke uten svakheter: Det digitale feltarbeidet har ingen "naturlige» grenser, og kan lede ulike forskere i ulike retninger (Van Duijn, 2020). Selv om eksempelstudien illustrerer tendenser observert i et større feltarbeid, kan den heller ikke uten videre generaliseres til RuNet som hele. Artikkelen må

\footnotetext{
${ }^{12}$ Marcus snakker også om å følge etter språklige bilder mer overordnet - «When the thing traced is within the realm of discourse and modes of thought, then the circulation of signs, symbols, and metaphors guides the design of ethnography.» (Marcus 1995, s. 109).

${ }^{13}$ Nøkkelordsøk etter Фроде/Фруде Берг (Frode/Frude Berg) i Yandex Novosti og Yandex Blogi (per definisjon åpne kilder) fra datoen Berg ble arrestert til to uker etter gjenkomsten til Norge. Tidsvinduet ble valgt for å fange opp reaksjoner underveis i saken, også umiddelbart etter Bergs løslatelse.

${ }^{14}$ Tidligere Russia Today.

${ }^{15}$ Datainnsamlingen fant sted mellom april og desember 2019.

${ }^{16}$ En nærmere diskusjon av de to nettverkene finnes i artikkelens analysedel.
} 


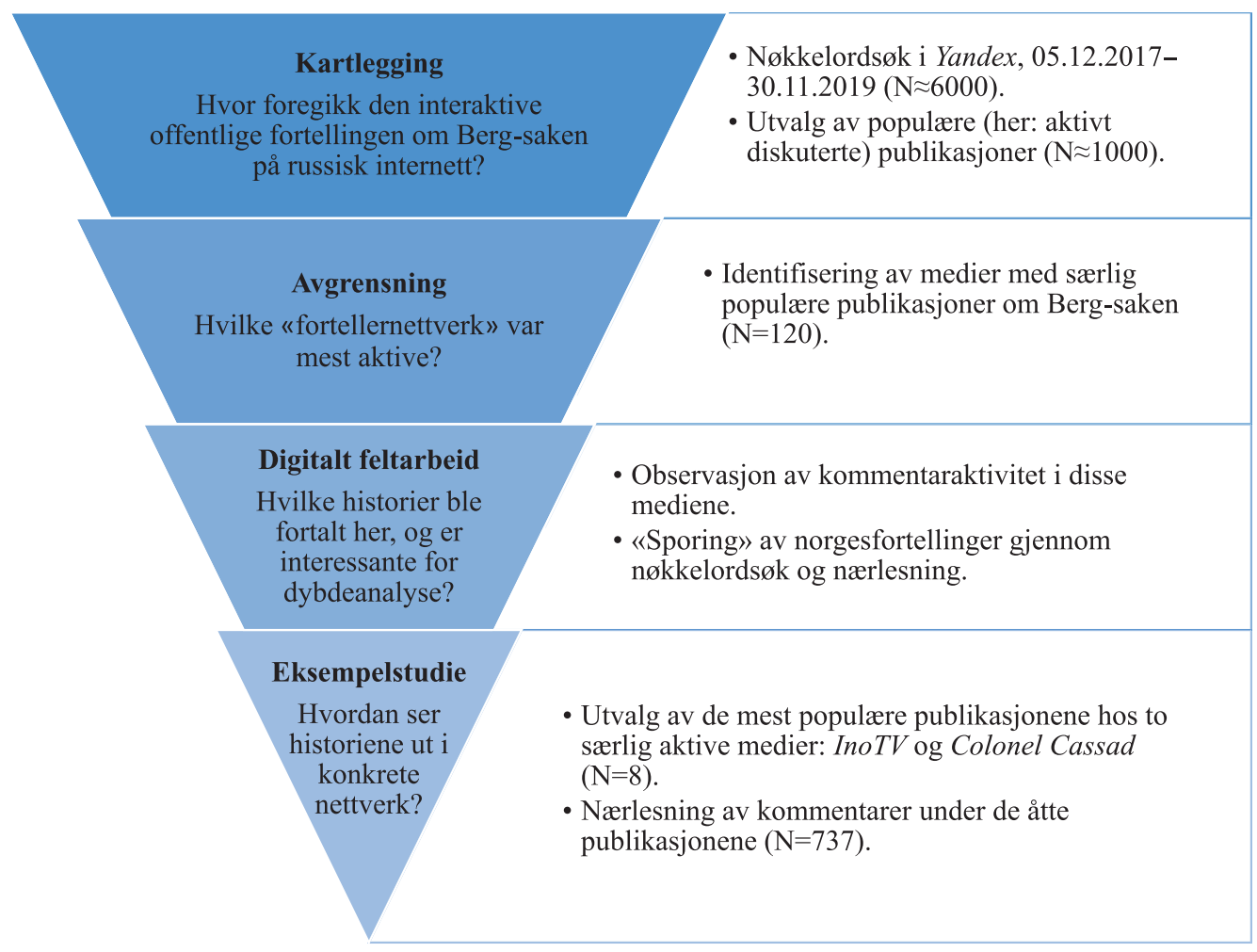

Figur 1. Framstilling av forskningsprosessen

videre leses i lys av den digitale etnografiens komplekse sammenfiltring av forsker og forskningsobjekt. ${ }^{17}$

\section{RuNet: Troll, bots, vatniki og "alle andre»}

For å forstå den russiske digitale historiefortellingen om Berg-saken, trenger vi en forståelse av den særegne kommunikasjonsdynamikken på RuNet. Sentralt for denne dynamikken er allestedsværende forsøk på manipulasjon: ${ }^{18}$ Siden den massive protestbølgen mot Putins presidentgieninnsettelse i 2012, der sosiale nettverk

\footnotetext{
${ }^{17}$ For en utdypende diskusjon om forskningsetiske utfordringer ved denne metoden, se De Seta (2020) og Markham (2020). Forskningsprosjektet denne artikkelen er del av følger veilederen for internettforskning fra Den nasjonale forskningsetiske komité for samfunnsvitenskap og humaniora (NESH) (2019), og har gjennomført personvernskonsekvensvurdering (DPIA) (Datatilsynet, 2019).

${ }^{18}$ Forsøk på å manipulere internettkommunikasjonen er langt fra unikt for Russland, men har blitt ensbetydende med digitale medier som sådan. Jeg vil likevel hevde at det gir mening å snakke om russisk internettmanipulasjon som noe eget, formet av særegne kulturelle betingelser - Russlands dypsittende logossentrisme og tyngden tillagt det skrevne ord; den asymmetriske politiske reguleringen av offentlig debatt i digitale versus tradisjonelle medier; landets sterke programmeringstradisjon
} 
var sentrale for mobiliseringen av demonstranter (Denisova, 2017), har avsløringer om Russlands massive digitale manipulasjonsindustri - særlig den notoriske "trollfabrikken» IRA - kommet på løpende bånd (Bradshaw et al., 2021; Garmazjapova, 2013; Korotkov, 2018; Rusajeva \& Zakharov, 2017; S. Walker, 2015). Russisk gravejournalistikk viste hvordan nettopp det omstridte presidentvalget var mål for en organisert trollkampanje: Brukerskapt innhold som støttet regimet og svertet opposisjonen oversvømte den russiske bloggosfæren, kommentarfelt og sosiale medier (Merkatsjeva, 2013). Lite tyder på at det siste tiårets negative mediafokus, særlig etter kontroversen rundt det amerikanske presidentvalget i 2016, har virket avskrekkende på Russlands digitale propagandakompleks. I stedet har dette blitt en konsolidert del av landets informasjonssfære - og kommentarfeltkultur (Beljaeva, 2019; Potsjeptsov, 2021; Voltsjek, 2021; Zakharov \& Rusjaeva, 2017).

De profesjonelle trollene er ofte uadskillelige fra såkalte vatniki, reelle brukere som kriger for regimet på RuNet. ${ }^{19}$ Det organiske innholdet fra disse brukerne smelter sammen med - og forsterker - organiserte påvirkningsforsøk (Voltsjek, 2021). Produksjonskapasiteten til profesjonelle troll og deres patriotiske stridspartnere blekner likevel sammenlignet med automatiserte aktører: I stedet for å manipulere og forvri meningsutvekslingen på RuNet, ligger bot-enes ${ }^{20}$ styrke i at de kan overdøve den fullstendig (Sanovich 2017, Stukal et al., 2017). Omfanget av denne overdøvelseskampanjen er potensielt enormt: NATOs strategiske kommunikasjonssenter (StratCom) ${ }^{21}$ har i perioder sporet $80 \%$ av den russiskspråklige tvitringen om alliansens tilstedeværelse i Russlands vestlige randsoner til bots (Fredheim, 2017). Senteret har også dokumentert at bot-aktivitet i russiske sosiale nettverk henger sammen med nyhetsbildet: Volumet av dataskapt propaganda øker rundt hendelser som berører NATOs forhold til Russland (Fredheim, 2021).

Dette dystre bildet til tross: RuNet har en sterk tradisjon for autentisk, aktiv debatt. Sosiale nettverk har hatt enorm betydning i Russlands ellers tungt regulerte medielandskap, der bloggsamfunnet Live fournal fremfor alt fikk funksion som «alternativ offentlighet» (Alexanyan et al., 2012; Etling et al., 2014). Tross fremveksten av kontroll- og overvåkningstiltak tilknyttet Kremls kamp for et suverent internett (Human Rights Watch, 2020), er RuNet fortsatt grunnleggende polyfont og mangfoldig (Kolozaridi \& Dovbysh, 2020). Dette utfordrer forestillinger om

og ekspansive tek-sektor, m.m. En nærmere diskusjon av de særegne betingelsene for Russlands digitale manipulasjonsbransjen finnes hos bl.a. Sanovich (2017).

${ }^{19}$ Vatniki var opprinnelig et skjellsord brukt av regimekritiske stemmer mot sine «motstandere», men har gradvis blitt appropriert av motstanderne selv.

${ }^{20}$ Automatiserte programvareagenter som kan simulere menneskelig adferd.

${ }^{21}$ Selv om StratCom ikke formelt er underlagt NATOs kommandostruktur, er dets forskningsvirksomhet unektelig knyttet til alliansens politiske og militære målsetninger. Senterets publikasjoner må sees i lys av dette. 
RuNet som ideologisk ekkokammer, og understreker betydningen av å utforske russiske digitale narrativ som noe mer nyansert enn en manipulerende maktmonolog fra Kreml.

\section{Russiske norgesnarrativ: Ambivalens og flertydighet}

Hvilke etablerte russiske norgesfortellinger dannet bakgrunn for den digitale historien om Berg-saken? Som den offisielle reaksjonen på hendelsen illustrerte, er Russlands narrativ om Norge ofte spenningsfylte. På den ene side blir grenseområdet i nord skildret som en unik fredssone forankret i godt naboskap, dialog og stabilitet (Godzimirski \& Sergunin, 2020; Käpylä \& Mikkola, 2015; Presidenten for Den russiske føderasjon, 2020). Utenriksminister Lavrov har framhevet Norges potensial som megler mellom Russland og NATO, og har kalt den norsk-russiske grensen Europas fredeligste (Lavrov sitert i TASS, 2019). Fredsutopien er imidlertid sårbar. Etter innlemmelsen av Krim og det stadig mer anspente forholdet til Vesten, identifiserer Allan og Lange-Ionatamišvili (2018, s. 12) et nytt trusselnarrativ i russisk nordområdediskurs: Russland advarer om at «importen» av spenning fra andre områder av utenrikspolitikken truer freden i Arktis. Wilhelmsen og Gjerde (2018, s. 3) finner i denne sammenheng at Norge i økende grad blir forstått som NATO $i$ nord - et verktøy i alliansens agenda om "holde tilbake» Russland. I offisiell diskurs blir NATOs nærvær i grenseområdene ikke bare sett som en voksende trussel mot Russlands suverenitet: Også Norges territorielle integritet og interesser er angivelig i krise. Wilhelmsen og Gjerde (2018, s. 4) observerer at "concerns about Norway's policy being dictated by its allies became increasingly central in Russian views of Norway».

De flertydige norgesfortellingene formidlet fra russiske myndigheter suppleres av en narrativ "gråsone ${ }^{22}$ kontrollert av dem (Abrams, 2016). Vestlig forskning på denne gråsonen har fremfor alt latt seg fascinere av $R T$, ut fra forestillingen om at kringkasteren kjemper i frontlinjen av Russlands informasjonskrig - som også foregår i Norden (Berzina et al., 2018; Cepurītis, 2021; Deverell et al., 2021; Wagnsson \& Barzanje, 2019). Selv på denne frontlinjen er Norge svøpt i flertydighet. På den ene siden inngår landet $i$ en større fortelling om nordisk-baltiske land som vasaller for USAs hegemoniske prosjekt, der paranoia, konspirasjonstenkning og "spionmani» gjennomsyrer forholdet til Russland (Berzina et al., 2018; Cepurītis et al., 2021). Samtidig skiller de "grå» norgesfortellingene seg ut: Der Danmark, og fremfor alt Sverige, fremstilles som feilede samfunn i moralsk forfall (se også Wagnsson \& Barzanje, 2019), skildres Norge som et land med et spesielt - om ambivalent - forhold til Russland. ${ }^{23}$ At

\footnotetext{
${ }^{22}$ Abrams hevder at dagens Russland har videreført det sovjetiske spekteret av påvirkningsaktiviteter i form av "hvit», "grå» og «svart» propaganda (jf. tradisjonelt diplomati, (des-)informasjonsvirksomhet og militære påvirkningsoperasjoner).

${ }^{23}$ Fortellingen om et «spesielt forhold» gjelder også Finland, det eneste andre nordiske landet som deler grense med Russland.
} 
Norge både figurerer som venn (jf. grensesamarbeidet i nord) og fiende (jf. amerikanske soldater på norsk jord), gjør landet til en grunnleggende uforutsigbar og uransakelig aktør (Deverell et al., 2021, s. 28).

Med den bakenforliggende kommunikasjonskonteksten tatt i betraktning, beveger vi oss nå til analysen.

\section{USAs skjødehund? En «propagandaføljetong»}

Feltarbeidet beskrevet tidligere i artikkelen viste at en av de største og mest populære bloggene på Live fournal, Colonel Cassad: Den totalitere propagandaens talerør, ${ }^{24}$ fungerte som et «leirbål» for russisk digital historiefortelling om Berg-saken. Som del av det selvtitulerte patriotiske digitale informasjonsprosjektet Russkij Ekspert (Ruxpert) har Colonel Cassad posisjonert seg som en innflytelsesrik prorussisk ${ }^{25}$ nettdebattant - særlig gjennom kommentarvirksomhet til støtte for innlemmelsen av Krim og separatistbevegelsene i Øst-Ukraina (Ruxpert, 2020; Vikirealnost, 2021). StratCom har kalt bloggen en pro-Kreml proxy for russiske påvirkningsoperasjoner mot de nordiske landene ved å spre desinformasjon om separatistiske stemninger i regionen (Cepurītis, 2021, s. 68). ${ }^{26}$ Colonel Cassads (2018a, b, c, d) digitale føljetong om Berg-saken - fire blogginnlegg med Berg-saken som hovedtema, rammet inn som en «fortsettelseshistorie» om norsk spionasje ${ }^{27}$ - fikk dermed stor resonans på RuNet. ${ }^{28}$

Et overgripende narrativ i denne fortsettelseshistorien er at Norge er USAs vasall i stormaktkonkurransen om det høye nord. Hos Colonel Cassad går den kjente tropen fra Kremls norgesfortellinger imidlertid gjennom en metamorfose fra den politiske til den dyriske verden: Der nordmennene tidligere «alltid har sett ut som 'grå mus' (seryje mysjki)", forsvinnende små og umerkelige sammenlignet med gigantene USA og Russland, fremstår de etter spionskandalen i spisshundens (sjpits) skikkelse (colonelcassad, 2018a). Bakgrunnen for hamskiftet var avsløringen om at Berg-saken ikke var unik, men skjedde i en større kontekst av samarbeid mellom norske og amerikanske etterretningstjenester (se også Lusberg \& Sørenes, 2018). Hvordan dette samarbeidet - og den norske hunden - ser ut, er imidlertid uklart: Den flertydige kategorien sjpits rommer alt fra ulvelignende polarhunder til

\footnotetext{
${ }^{24}$ I tillegg til over fem millioner månedlige bloggbesøk (per mai 2021) har Colonel Cassad titusenvis av følgere i andre sosiale nettverk som Telegram og Twitter.

${ }^{25}$ Termen brukes av Ruxpert-prosjektet selv i sin oversikt over individer og grupper som «forsvarer et prorussisk (prorossijskij) perspektiv på RuNet» (Ruxpert, 2020).

${ }^{26} \AA ̊$ se Colonel Cassad som en frontkjemper for regimet er nok en forenkling. Bloggeren betegnes gjerne som kommunist, og har kommet med hard kritikk mot styringspartiet Forent Russland. Mer fruktbar er nok den flertydige kategorien gosudarstvenniki - en løst organisert gruppering av RuNet-debattanter som tar til orde for en autoritær russisk stat.

${ }^{27}$ Berg-saken ble nevnt på bloggen i flere andre tilfeller, men disse fire innleggene står i en særstilling.

${ }^{28}$ I tillegg til kommentaraktiviteten på Colonel Cassads egen blogg ble innleggene flittig delt og diskutert videre på andre deler av Live fournal og RuNet ellers.
} 
miniatyrhunder som passer $\mathrm{i}$ en håndveske, og Colonel Cassad tegner henholdsvis Norge både som driftssterk sporhund med «eksepsjonelle [etterretnings-] evner» og veik skjødehund som «aktivt utnyttes av sine amerikanske kolleger i den hemmelige krigen mot Russland" (colonelcassad, 2018a). Dyresymbolikken i Colonel Cassads fortelleruinvers kompliseres ytterligere når Norge i en seinere bloggpost forvandles på nytt: «[Det amerikansk-norske etterretningssamarbeidet] minnet om hvordan en hunnkatt lærer kattungene sine å jakte og fange mus» (colonelcassad, 2018d).

Over vrimlet av dyrebilder, der Norge veksler fra mus til hund til katt som jakter mus, står en mer entydig forestilling: Berg-saken er del av en ny kald krig. Ut fra denne forestillingen leser Colonel Cassad spionskandalen som fullstendig forutsigbar: «krigen mellom spesialtjenestene får stadig mer moment, som seg jo hør og bør under en kald krig» (colonelcassad, 2018d, egen utheving). Berg-saken reflekterer en form for historisk kontinuitet: «Norge drev med dette i den forrige kalde krigen, og vil drive med det samme også gjennom denne ( $i$ v khode tekusjtsjej)" (colonelcassad, 2018a). Colonel Cassads fortelling om spionskandalen som påfallende lite oppsiktsvekkende - «en vanlig sak» (colonelcassad, 2018c), resonerer med Russlands offisielle reaksjon på hendelsen. Den nøkterne tonen har imidlertid ingen gjenklang i kommentarfeltet under Colonel Cassads føljetong på Live fournal, der brukerne i stedet går til angrep på det de oppfatter som en hensynsløs amerikansk imperialistisk konspirasjon:

Bruker 1: De [pindosene ${ }^{29}$ har utnyttet sine nordlige vasaller siden $1949 .{ }^{30}$ I alle retninger, og hvert eneste år. Hvor mange kampøvelser har ikke det allestedsnærværende [etterretningsskipet] Marjata ${ }^{31}$ alene [plaget] nordsjøfolket med. De små, men stolte baltiske landene, fattigslige Romania har allerede «falt for amerikanernes føtter», og i dag er det de skandinaviske statene som legges i ruiner. Alt etter Langleys nøye utarbeidete og vellykkede metode. Det er ingenting i veien for at [russiske sikkerhetstjenester] kan knuse skandinavene og rumenerne [for å beskytte seg selv].

Bruker 2: Og hvorfor legges [disse landene] i ruiner?

Bruker 3: Fordi de er tvunget til å styre [landet sitt] ikke ut fra egne interesser, men ut fra «ønskelisten» til sin overherre (siuzeren) (Under colonelcassad, 2018d) ${ }^{32}$

For noen kommentatorer viser spionskandalen altså et Skandinavia på randen av kollaps. USA har allerede underlagt seg (og følelig ødelagt) flere tidligere sosialistiske land. Nå er det Norge - en vasall helt siden NATOs stiftelse - som knuses i amerikanernes jerngrep. Norsk etterretning er dermed nettopp ikke norsk: Der den dikteres

\footnotetext{
${ }^{29}$ Hyppig brukt skjellsord for amerikanere.

${ }^{30}$ Årstallet NATO ble stiftet.

${ }^{31}$ Norsk etterretningsskip innviet i 2014. Med hjemhavn i Kirkenes har skipet hatt hovedfokus på den russiske Nordflåten.

${ }^{32}$ Jeg gjengir utvekslingene i kommentarfeltet så direkte som mulig, og kommentarenes rekkefølge er reell. I originalmaterialet er imidlertid utvekslingene ofte spredt ut i tid og rom, perforert av parallelle diskusjoner, irrelevante kommentarer og spam fra andre brukere. Kommentarfeltene er dermed mer kaotiske og komplekse enn hva denne artikkelen reflekterer.
} 
fra motsatt side av Atlanterhavet tjener den militære aktiviteten i nordområdene ikke nordmenn, men amerikanere. For den norske befolkningen er krigsmaskineriet i det høye nord tvert imot en plagsom parasitt. I kommentarfeltet blir dette narrativet $\mathrm{i}$ siste instans brukt for å legitimere et russisk angrep som kan «giøre idiotene om til atomstøv (jadernyj pepel)" (Bruker 4 under colonelcassad, 2018a). Norge er tross alt ikke lenger en suveren stat, men "en koloni-filial for USAs [væpnede styrker]" (Bruker 5 undercolonelcassad, 2018d).

Langs denne plottlinjen handler ikke spionskandalen om det norsk-russiske forholdet, men om vestlige stormakters grenseløse brutalitet. Berg-saken leses inn i en krigskrønike der «amerikanerne begynte den brutale retorikken om [Syria], England presser det russiske sporet i forgiftningen av tidligere overløpere, ${ }^{33}$ til og med lille Macron rister av lyst etter å bombe noen» (Bruker 6 under colonelcassad, 2018d). Det er altså verdensledere fjernt fra Russlands grenser heller enn Norge som definerer saken for Live fournal-brukerne.

Krigskronikørene får imidlertid ikke stå uimotsagt:

Bruker 7: Tenk, ikke alle i den forbannede vesten deres vil ha en ny kald krig. Det er hos oss at Putinistene (zaPutintsy) ivrig hopper av gårde for å kjempe på Abramovitsjs $^{34}$ og Prigozjins ${ }^{35}$ regning. Ja, dagens Russland er ikke USSR, med sitt potensial. Men før [landet] lovmessig går i oppløsning kan det forgifte (...) $j^{\star}$ vlig mange mennesker

Bruker 8: Ut fra det rælet du lirer av deg, er det deg vi har forgiftet (...) :)))) [Slettet kommentar] ${ }^{36}$

Bruker 7: Hva var det den idioten [sa] om ukrainerne (khokhly). ${ }^{37}$ Hva så med ukrainerne? Har de frosset i hjel allerede? Gått i oppløsning?

Bruker 8: Kaklo, ${ }^{38}$ er du svimmel eller er du allerede begynt å fryse?

Bruker 9: Så hva, har [ukrainerne] virkelig ikke gått i oppløsning?? Hvem er det som har (tsjej) Krim?)) ${ }^{39}$ (under colonelcassad, 2018a)

\footnotetext{
${ }^{33}$ Berg-saken overlappet i tid med Storbritannias anklager om at Russland stod bak den mye omtalte forgiftningen av tidligere dobbeltagent Sergej Skripal (mars 2018). På RuNet ble de to hendelsene ofte diskutert i forlengelsen av hverandre.

${ }^{34}$ Roman Arkadjevitsj Abramovtisj, en av Russlands rikeste menn. Han havnet i britenes søkelys etter forgiftningen av Sergej Skripal (Krutov, 2018).

${ }^{35}$ Jevgenij Viktorovitsj Prigozjin, «Putins kokk» som angivelig står bak trollfabrikken i St. Petersburg (se bl.a. Korotkov, 2018).

${ }^{36}$ Utvekslingen tydeliggjør den fragmentariske og flyktige dimensjonen av nettdebatt. Det er tydelig at kommentatoren reagerer på innlegget som i ettertid har forsvunnet, og som han selv ikke helt fikk med seg. At kommentarer kan slettes - både av plattformen og brukeren selv - påvirker uunngåelig den meningsskapende prosessen.

${ }^{37}$ Khokhly (flertall av khokhol) er et russisk kallenavn på ukrainere. Begrepet kan ha nedlatende konnotasjoner, og brukes i russisk nettdebatt ofte som motsats til vatniki.

${ }^{38}$ Fra khokhol.

${ }^{39} \mathrm{På}$ RuNet uttrykkes smileys ofte bare med parentes.
} 
Denne utvekslingen er interessant av tre grunner: For det første viser den hvordan Russlands kamp om narrativene - og "aktive tiltak»" ${ }^{40}$ mer overordnet - er en eksplisitt uttrykt og kontroversiell del av russisk nettdebatt. En sentral referanse her er ansvarsspørsmålet rundt tiltakene som innbefatter alt fra forgiftninger til internettrolling, og de dunkle forbindelsene mellom russiske myndigheter og oligarker i denne sammenheng (jf. Korotkov, 2018; Krutov, 2018). En annen referanse er Kremls narrativ om et Ukraina i ferd med å falle fra hverandre, blant annet fordi ukrainerne er så avhengige av Russland at de risikerer å fryse i hjel etter å ha stengt for russisk gassimport (EUvsDisinfo, 2019). Basert på disse referansene hevder en regimekritisk kommentator at det er Russland, ikke Vesten, som hisser til krig.

Den andre grunnen til at utvekslingen er interessant, handler om at den kritiske brukeren umiddelbart angripes av en trollbrigade: et kollektiv av brukere som gjennom latterliggjøring og provokasjon stripper kommentaren - og kommentatoren - for legitimitet. Selv om slike brigadeangrep ofte består av brutale verbale angrep, ${ }^{41}$ kan de også være mer subtile: Gjennom tynn (tonkij) trolling blir brukerens egne kommentarer overtatt, snudd på hodet og brukt som våpen - ofte ladet med komikk - i kommentarkrigen mot ham (Zvereva, 2020). I eksempelet skjer dette ved at den regimekritiske brukeren forflyttes til et oppløst Ukraina som forgiftet og forfrosset offer for sine egne anklager mot Russland. Angrepet handler ikke om å overbevise ham eller andre Live fournal-brukere om at det kritiske narrativet er falskt. I stedet saboterer trollene samtalen ved å omskape den til et satirespill der offeret står igjen som en hjelpeløs brikke. Ethvert potensial for kritisk debatt blir effektivt nøytralisert, ${ }^{42}$ mens trollbrigaden kan «le hele veien til Krim».

Den tredje grunnen til at eksempelet er interessant, er illustrasjonen av hvordan nettverksfortellingene om Berg-saken på et eller annet punkt ubønnhørlig gjennomgikk et narrativskifte fra konflikten med Norge til konflikten med Ukraina. For RuNet-brukerne var de tilsynelatende adskilte feltene uløselig sammenknyttet.

\section{Berg-saken som informasjonsvåpen}

Et annet overgripende narrativ i nettverksfortellingene om Berg-saken, er at den ble brukt som våpen i en informasjonskrig. Dette narrativet var spesielt produktivt blant brukere av $R T s$ plattformer, fremfor alt $I n o T V-« R T s$ russiskspråklige vindu til utenlandske mediers verden». I det russiske digitale medielandskapet har InoTV posisjonert seg nettopp som et narrativprosjekt: Nettstedet publiserer ikke bare oversettelser (perevody) av fremmedspråklig nyhetsinnhold, men også omfortellinger

\footnotetext{
${ }^{40}$ Aktyonyje meroprijatija. Et spekter av fordekte metoder brukt i politisk påvirkningsøyemed. Se Abrams (2016) for nærmere diskusjon.

${ }^{41}$ I russisk internett-folklore kalt travlja eller tosltyj (tykk) trolling.

${ }^{42}$ For en studie av hvordan russisk internettrolling nøytraliserer politisk debatt, se Kurowska \& Reshetnikov (2018).
} 
(pereskazy). Fortellerprosessen blir sett som nødvendig for å gi publikum et «mest mulig komplett bilde» av hvordan utenlandske medier omtaler Russland (InoTV, u.å.).

Premisset om at nyhetsbildet nettopp er et formbart og fleksibelt narrativ som først får sin fulle betydning giennom kreativ med-fortelling, reflekteres i InoTVs aktive kommentarfelt: Én nyhetssak om Berg-saken kunne trigge over 270 kommentarer (InoTV, 2018a). Et annen viktig premiss for historien om spionskandalen hos InoTV, var at nettstedet ikke delte noen norske nyhetssaker om hendelsen med sine brukere. Historien om Berg-saken ble formidlet giennom amerikanske, engelske og andre europeiske lands medier, løsrevet konteksten av norsk-russiske forbindelser. Norge forsvant dermed inn i bakgrunnen av den større, veletablerte konspirasjonsfortellingen om Washingtons angrep på Moskva. I den grad nordmennene overhodet er involvert i denne fortellingen, er det som ofre for et "amerikos ${ }^{43}$-komplott» (Bruker 10 under InoTV, 2018a). Dette komplottet går langt ut over etterretningsområdet: Berg, og Norge mer overordnet, misbrukes i amerikanernes antirussiske propaganda. Kommentarene under en "omfortalt» Washington Post-artikkel (InoTV, 2018a) om hvordan spionskandalen speiler splittelse i det norsk-russiske forholdet er illustrerende:

Bruker 11: Dette er en pindos-utgivelse, som betyr at i artikkelen blir reelle hendelser forvridd [for å passe] inn i deres nødvendige fortolkningsmønster, smakt til med en syk fantasi, det er på tide å bare overse det disse paranoide schizofrenikerne skriver i vei om.

Bruker 12: Det ser ut som de har brukt nordmannen... For å eskalere. [Han er] en kjent figur i visse kretser, ikke russofob, livshistorien [hans] har også bare vært til nytte for forbindelsene med Russland... Og nå sier de - se hva det røde Mordor $^{44}$ holder på med!

Det er morsomt å lese sånt, "tredjeparten» (vi kaller den det) bestemte seg for å sette russerne og nordmennene opp mot hverandre, og Washington Post hentet lykkelig pinnen som ble kastet (denne artikkelen) etter ordre fra "tredjeparten».

Bruker 13: Krigspropaganda. $\mathrm{R}^{\star}$ vhølene har blandet Kirkenes og de totalt utenforstående innbyggerne sammen med ett individ, den så langt ubestemmelige Berg, og på denne suppen brygger de en spådom om tredje verdenskrig. I virkeligheten er det på disse stedene til og med mellom grensevaktene på begge sider giensidige, personlige, vennlige forhold. Jævla WP vil ødelegge det. (Under InoTV, 2018a)

For disse kommentatorene er det ikke norsk spionasje som er en trussel, men det angivelig antagonistiske (og grunnleggende uvedkommende) amerikanske

\footnotetext{
${ }^{43}$ Synonym til pindos.

${ }^{44}$ Mordor-metaforen, som altså har blitt svært populær i russisk nettdebatt om forholdet mellom Russland og Vesten, kan spores tilbake til nettopp InoTV: Etter innlemmelsen av Krim publiserte nettstedet en Bloomberg-artikkel som sammenlignet ukrainerne med hobbiter og Putin med Sauron (InoTV, 2014).
} 
narrativet om den. Forestillingen om spionskandalen som del av en ny kald krig er i denne sammenhengen ikke bare farlig, men fullstendig fiktiv: Berg er ikke en angriper, og grensesonen er ikke er en krigssone. I sin febrilske jakt etter å bekrefte eget verdensbilde projiserer Washingtons propagandamaskineri «russofobi der den ikke finnes» (Bruker 14 under InoTV, 2019a). Det amerikanske nyhetsnarrativet forsøker ikke bare å forstyrre informasjonsstrømmen om Berg-saken, men å forvri og forgifte det norsk-russiske forholdet. For mange InoTV-brukere har dette forholdet nemlig vært eksepsjonelt vennskapelig, i skarp kontrast til forholdet Russland har med sine andre naboland - særlig Ukraina. Under en reportasje (InoTV, 2019b) om at innbyggerne i Kirkenes $i k k e$ vil spionere på sine naboer i øst, diskuteres denne kontrasten nærmere:

Bruker 15: I NATO ser man på muligheten for å umiddelbart bytte ut den norske befolkningen med ukrainske spioner )))

Bruker 16: Og nå for et øyeblikk se for dere befolkningen i okraina, ${ }^{45}$ som fikk et lignende forslag?

Bruker 17: Nettopp på grensen mellom Norge og USSR er det forresten et sted der de tysk-fascistiske okkupantene ikke fikk krysset grensen under Den store fedrelandskrigen. ${ }^{46}$ I tillegg til den sovjetiske hærens heroiske motstand ble tyskerne [angrepet] bakfra av lokalbefolkningen i Norges grenseområde.

Bruker 18: Demokratiforrædere! De skjøt uskyldige Wehrmacht-offiserer i ryggen!

Bruker 19: Og nå er det NATOs krigsidioter som har kommet fram [til grensen].

Bruker 20: Nordmennene er ikke banderiter ${ }^{47}$ presset ut av polakkene, de lar ikke seg selge for truser. (Under InoTV, 2019b)

Denne kaotiske utvekslingen viser på nytt at Ukraina-konflikten alltid ulmer under overflaten av norgesdebatt på RuNet. Mens nordmennene er «flinke (molodtsy), frie mennesker, uten komplekser» (Bruker 21 under InoTV, 2019b), er ukrainerne deres antitese: svake, svikefulle og villige til å gjøre hva som helst for tilgang til eksklusivt europeisk undertøy - en referanse til russiske regimetro mediers latterliggjøring av kravene under Euromajdan (Svazovskij, 2018). Samtidig viser eksempelet hvor viktig krigsminnet i nord er for russiske digitale narrativ om Norge. Fortellingen om den felles kampen for frihet er ikke bare en død diplomatisk klisjé hostet opp av Lavrov under frigjøringsjubileet: den er fortsatt høyst levende på RuNet (Kalsaas, 2020). I denne digitale minnekulturen der fortid, nåtid, historie og politikk smelter sammen, blir dagens militarisering av nordområdene for mange en rein forlengelse av andre verdenskrig. NATO-styrkene er uadskillelige fra Wehrmacht, mens demokratiets og nazismens fanebærere glir over i hverandre. Slik Norge måtte velge «rett side» av

\footnotetext{
${ }^{45}$ Det russiske ordet for periferi, til forveksling likt Ukraina. Brukes ofte av troll og vatniki i kommentarkrigene om Ukraina-konflikten for å alludere til at landet nettopp bare er en russisk «utkant».

${ }^{46}$ Russisk betegnelse på andre verdenskrig.

${ }^{47}$ Tilhengere av Stepan Bandera, den ukrainske ultranasjonalisten som samarbeidet med tyskerne i de tidligere fasene av nazistenes angrep på Sovjetunionen.
} 
historien under krigen, står de også i nettverksfortellingene om Berg-saken foran et historisk skjebnevalg: okkupasjon (i fortiden av tyskerne, i fremtiden av amerikanerne) eller frihet.

Selv om InoTVs raison d'être er å eksponere ikke-russisk nyhetsdiskurs, kretser narrativene i kommentarfeltet stadig tilbake til det russiske informasjonslandskapet. Under en artikkel om at Berg innrømmet å ha vært kurer for norsk etterretning skriver en kommentator syrlig "[Jeg] husker at allslags Novaja Gazeta-er og Ekho Moskva-er ${ }^{48}$ fabulerte om at de blodtørstige KGB-sjnikiene hadde arrestert en pensjonist. Og nå ser du hvordan det endte opp. Slik det forresten alltid gjør med disse ikke-mediene (nedoSMI)" (Bruker 22 under InoTV, 2018b). I flere brukeres øyne har russiske uavhengige medier utnyttet Berg-sakens evne til å sette Russlands maktapparat i dårlig lys, og gjort nordmannen til våpen i sin paranoide kamp mot forestilte fiender i FSB. Spionskandalen blir gjennom nettverksfortellingene dermed viklet inn en informasjonskrig som ikke bare utkjempes med Vesten, men også innenfor landets grenser.

Narrativet om at Berg-saken misbrukes og manipuleres av Russlands uavhengige pressekorps leder tilbake til Live fournal og Colonel Cassad. I en harselas med Novaja Gazetas (Britskaja, 2017) fortelling om Berg som offer for den russiske sikkerhetstjenestenes brutale historie, stempler Colonel Cassad (2018b) den regimekritiske dekningen av spionskandalen som en "desinformasjonskampanje». Offerfortellingen om Berg har etter innrømmelsen av kurervirksomhet vist seg å være falsk, og Novaja Gazeta og deres kolleger er strippet for journalistisk legitimitet. I kommentarfeltet spekuleres det videre om hvilke narrative krumspring som venter i den russiske uavhengige mediedekningen av Berg-saken:

Bruker 23: Nå kommer alskens Ekho Moskvy til å gå ut av sitt gode skinn, [og si] at de blodtørstige tsjekistene ${ }^{49}$ torturerte en uskyldig nordmann til tilståelse i månedsvis, mens han, styrket av demokratiets kraft holdt ut og ga [seg ikke over] til bødlene, ved å bare delvis innrømme spionasje.

Bruker 24: For den astronomiske summen av 3000 euro $^{50}$ skulle han kjøpe et parti bloggere, ingenting annet

Bruker 25: svar til Bruker 23: Han er uskyldig, så klart! Og innrømmelsen slo de ut [av ham] i fangekjelleren! Puuuh, jeg kan puste ut... Du, borger, har reddet verdensbildet mitt, takk skal du ha, takk!!! (Under colonelcassad, 2018b, egen utheving)

I utvekslingen ser vi tydelig avtegninger av den karikerte martyrlegenden fra artikkelens innledning: Parodien på en hyperbolsk heltefortelling, der demokratiikonet Berg seirer over de demoniske undertrykkerne i FSB, spotter regimekritiske lesninger av hendelsen både i de uavhengige journalistenes reportasjer og i kommentarfeltene

\footnotetext{
${ }^{48}$ To av tungvekterne i Russlands uavhengige medielandskap.

${ }^{49}$ Tsjekaen var det hemmelige politiet etablert av Lenin, forløperen til KGB.

${ }^{50}$ Pengebeløpet Berg hadde med seg da han ble pågrepet.
} 
under dem. For disse brukerne har historien om spionskandalen blitt til en sirkusforestilling der Russlands opposisjonelle tar rollen som klovner. ${ }^{51}$

Utvekslingen viser igjen hvordan spørsmålet om digital manipulasjon - i likhet med spørsmålet om Ukraina - løper som en rød tråd gjennom brukerdebattene på RuNet. Referansen til nettdebattanter som kan kjøpes og betales reflekterer en sterk bevissthet om at brukerskapt innhold har blitt en attraktiv handelsvare på det russiske informasjonsmarkedet. Bevisstheten om å stå midt i skuddsonen for kampen om narrativene preger utvekslingene rundt Berg-saken både eksplisitt, i form av nådeløs harselas med «motstandernes» historiefortelling, og implisitt, i form av dyp skepsis mot etablerte diskurser om hendelsen. De russiske nettverksfortellingene om Berg-saken formet dermed en større metafortelling om den digitale propagandaens kompleksitet: Spionskandalen ble på den ene siden sett som våpen $\mathrm{i}$ informasjonskrigen rettet mot RuNets brukere, samtidig som den trigget «borgerkriger» mellom brukerne selv.

\section{Avsluttende diskusjon}

Som illustrasjon av et større digitalt feltarbeid har jeg i denne artikkelen foretatt en eksempelstudie av kommentaraktivitet om Frode Berg-saken på InoTV, RTs russiskspråklige «vindu» til utenlandske medier, og Colonel Cassad, en prominent blogger i det russiske segmentet av Live fournal. Ut fra interaktiv digital narrativteori har jeg i studien lest kommentaraktivitet på disse plattformene som nettverksfortellinger: Tilpasningsdyktige narrativ med «åpen slutt», karakterisert av oppsplittet forfatterskap, form og innhold. Slike fortellinger lar seg ikke fange av idéen om narrativ enhet, som har vært styrende for eksisterende forskning på russiske narrative offensiver mot Norden.

Studiens empiriske grunnlag er vanskelig å plassere innenfor denne tidligere tenkningen rundt Russlands kamp om narrativene. ${ }^{52} \mathrm{Vi}$ vet ikke hvem som har skrevet kommentarene, og om noen av dem er profesjonelle troll eller bots - selv om dette, statistisk sett, er svært sannsynlig. Vi vet heller ikke i hvilken grad de digitale narrativene reflekterer en fordekt kommunikasjonsstrategi om spionsaken fra russiske myndigheter. Denne usikkerheten er likevel ikke noe som nødvendigvis hindrer oss fra å forstå hvordan russisk digital propaganda om Norge ser ut. Usikkerheten er en uadskillelig del av kampen om narrativene på RuNet. Kampen er nettopp en

\footnotetext{
${ }^{51}$ Colonel Cassad (2018b) bruker selv begrepet «klovner» i sin omtale av russiske uavhengige journalisters dekning av Berg-saken.

${ }^{52}$ Fokuset har her ofte vært på (1) hvem som står bak (enten dette er det russiske maktapparatet selv, mellommenn i det statlige mediekomplekset eller den private manipulasjonsindustrien); (2) skillet mellom organisert og organisk innhold (e.g. fokuset på å avdekke falske brukere og koordinerte russiske desinformasjonskampanjer); og (3) idéen om at propagandaen skapes på ett nivå (e.g. sentralt politisk hold) og formidles på et annet (e.g. sosiale nettverk), og dermed har tydelige grenser mellom avsender, medium og mottager.
} 
samhandling mellom målrettede manipulasjonsforsøk, reelle meninger, lek, alvor og nettverkenes egen kommunikasjonslogikk som er nærmest umulig å overskue - $i$ alle fall fra brukernes ståsted. Russlands informasjonsoffensiv lar seg vanskelig utkrystallisere fra dette samspillet. En slik utkrystallisering har heller ikke vært artikkelens hensikt. I stedet vil jeg hevde at russisk narrativkamp, også knyttet til Norge, får sin betydning nettopp gjennom den rådende usikkerheten og de komplekse samhandlingene i nettverkene. ${ }^{53}$

Hvilke utslag fikk disse samhandlingene for den russiske digitale historiefortellingen om Berg-saken? Fra nettverksperspektiv avtegnet norgesfortellingene rundt spionskandalen seg som langt mer splittet - og splittende - enn fra sentralt hold. Den brukerstyrte historiefortellingen bevegde seg langs en rekke ulike plottlinjer, der protagonist, antagonist og konflikten mellom dem var langt fra stabile størrelser. Én plottlinje handlet om at Berg-saken, på tross av at den mangler sidestykke i norsk-russisk historie, reflekterer kontinuitet i forholdet mellom to land $i$ krig. Heller enn en selvstendig krigførende nasjon er Norge her en plattform for de imperialistiske vyene til en okkupasjonsmakt. Spionskandalen er dermed ikke bare en forlengelse av den kalde krigen, men, for noen brukere, andre verdenskrig. Her ser vi altså at nettverksfortellingene speiler det kanskje viktigste narrativet i Den russiske føderasjonens identitetsprosjekt under Putin: Den store fedrelandskrigens altoverskyggende betydning.

Langs en alternativ plottlinje blir nettopp «krigsnarrativet» sett som det sentrale problemet ved Berg-saken. Narrativet, et produkt av amerikansk propaganda, forsøker å skape splittelse i et godt norsk-russisk naboskap. I denne fortellingen er Norge, ikke Russland, spionskandalens egentlige offer. Nordmennene misbrukes i USAs voldelige informasjonskrig. En motstridende - og svært omstridt - plottlinje plasserer Russland i rollen som informasjonskrigens antagonist. En tredje plottlinje forflytter konflikten i Berg-saken fra stormaktspolitikken til det russiske medielandskapet, der sakens antagonister er Russlands uavhengige presse. De ulike plottlinjene skaper samtidig en større metafortelling om manipulasjon som en iboende del av russisk internettkommunikasjon.

Et samlende trekk ved de ustabile fortellingene om spionsaken er likevel at Berg og Norge nettopp ikke spiller hovedrollen. Historien handler i stedet først og fremst om Russlands forhold til USA og, i andre rekke, deres allierte. Den mest sentrale konflikten i dette forholdet kretser heller ikke rundt den norsk-russiske grensen og militariseringen av det høye nord. I stedet er det Ukraina-spørsmålet som

\footnotetext{
${ }^{53}$ Som Thomas Rid skriver i sin analyse av hvordan denne kompleksiteten påvirker dagens «aktive tiltak»: «It is very hard to distinguish - for an activist, for the target of an active measures campaign, even for a large organization running its own active measures - between a cunning influence agent on the one hand, and a genuine activist on the other. (...) In practice, one individual can be both genuine and exploited asset, a witting and unwitting collaborator at the same time. (...) Active measures are therefore difficult to contain conceptually, with no obvious beginning or end» (Rid, 2020, s. 432-433).
} 
langt på vei blir toneangivende for russiske nettverksfortellinger om Berg-saken, slik det var toneangivende for reaksjonen fra Kreml. Både i offisielle uttalelser og på nett ser vi et narrativskifte: Historien transporteres fra Barents- til Svartehavet, fra en spionklaget nordmann til en større vestlig kampanje mot russiske interesser i det post-sovjetiske området. I den brukerdrevne kommunikasjonen får dette narrativskiftet store konsekvenser for konfliktnivået: Tidvis kan historien om Frode Berg på RuNet ligne en gigantisk khokhlosratsj ${ }^{54}$ - det karakteristiske fenomenet $\mathrm{i}$ russisk internettkommunikasjon "etter Krim» der diskusjon om Ukraina kollapser i voldsomme kommentarkriger. Først når fokuset i debattene rundt Berg-saken skifter fra Norge til Ukraina observerer vi åpenbar trolling av regimekritiske stemmer i kommentarfeltet.

Det er sterke forbindelseslinjer mellom nettverksfortellingene og dypt forankrede, myndighetssanksjonerte «mesterfortellinger» om det norsk-russiske forholdet. Det mest interessante ved forholdet mellom den brukerdrevne og offisielle historien om Berg-saken, er kanskje likevel dets asymmetriske struktur: Der Kremls reaksjon på Berg-saken karakteriseres av narrativunderskudd, en nærmest monolittisk motstand mot å fortolke hendelsen, bærer reaksjonen på RuNet preg av narrativoverflod. I stedet for å "lukke» saken etter modell fra russiske myndigheter, åpner nettverkene den opp som en mosaikk av mulige, ofte motstridende, betydninger. Den tilsynelatende urokkelige stabiliteten $i$ offisielle narrativ erstattes her av en langt mer volatil og tidvis eksplisitt voldsforherligende norgesfortelling.

Kontrasten mellom den avmålte offisielle og eksplosive brukerdrevne reaksjonen på Berg-saken viser hvordan digitale medier gjør det nødvendig å tenke nytt om det norsk-russiske forholdet. De digitale narrativene utfordrer radikalt hvordan Norge konstrueres i det russiske informasjonslandskapet, samtidig som de er en rik kilde til russiske forestillinger om Norges posisjon $i$ den pågående kampen om narrativene. I denne sammenheng kan Norges tross alt perifere rolle i nettverksfortellingene om Berg-saken peke mot at landet er "fanget i kryssilden» heller enn et primært mål for Russlands kommunikasjonsoffensiv. De faktiske forbindelsene mellom det «formelle» Russland og de uformelle aktivitetene på nett - narrativet om informasjonskrigen og de politiske realitetene av den - er likevel et felt med behov for langt mer forskning.

\section{Om artikkelen}

Ingunn Lunde, Jardar Østbø, Kåre Johan Mjør og to anonyme fagfeller har bidratt til å forbedre artikkelen gjennom grundige lesninger og verdifulle tilbakemeldinger. Artikkelen ble ferdigstilt under et gjesteopphold på Aleksanteri-instituttet ved universitetet i Helsinki høsten 2021.

\footnotetext{
${ }^{54}$ En ikke-russisk analogi til internettfenomenet sratsj er «shitstorm»- en eksplosiv, ekstremt kontroversiell og destruktiv diskusjon. Her er det altså snakk om en «ukrainer-shitstorm».
} 


\section{Referanser}

@dw_russian. (2019). Srok ot 8 do 14 let grozit norvezjtsu Frode Bergu za predpolagaemyj sjpionazj v Rossii (...). Twitter. https://twitter.com/dw_russian/status/1115605251761950725

Abrams, S. (2016). Beyond propaganda: Soviet active measures in Putin's Russia. Connections, 15(1), 5-31.

Airoldi, M. (2018). Ethnography and the digital fields of social media. International fournal of Social Research Methodology, 21(6), 661-673.

Alexanyan, K., Barash, V., Etling, B., Faris, R., Gasser, U., Kelly, J., Palfrey, J. \& Roberts, H. (2012). Exploring Russian cyberspace: Digitally-mediated collective action and the networked public sphere. Berkman Center Research Publication.

Allan, I. \& Lange-Ionatamišvili, E. (2018). Arctic narratives and political values. Russia, China and Canada in the High North. NATO Strategic Communications Centre of Excellence.

Aro, J. (2016). The cyberspace war: Propaganda and trolling as warfare tools. European View, 15(1), 121-132.

Asmolov, G. (2019). The effects of participatory propaganda: From socialization to internalization of conflicts. fournal of Design and Science, 6.

Beljaeva, J. (2019, 14. desember). «Fabriki trollej» - novyj standart v polititsjeskom piare? DW. https://www. $\mathrm{dw} . \mathrm{com} / \mathrm{ru} /$ фабрики-троллей-новый-стандарт-в-политическом-пиаре/a-51656603

Bergh, A. (2020). Påvirkningsoperasjoner $i$ sosiale medier-oversikt og utfordringer. Forsvarets forskningsinstitutt.

Berzina, I., Cepuritis, M., Kaljula, D. \& Juurvee, I. (2018). Russia's footprint in the Nordic-Baltic information environment (Rapport 2016/2017). NATO StratCom COE.

Boatwright, B. C., Linvill, D. L. \& Warren, P. L. (2018). Troll factories: The internet research agency and statesponsored agenda building. Resource Centre on Media Freedom in Europe.

Bradshaw, S., Campbell-Smith, U., Henle, A., Perini, A., Shalev, S., Bailey, H. \& Howard, P. N. (2021). Country case studies industrialized disinformation: 2020 global inventory of organized social media manipulation. Oxford Internet Institute.

Britskaja, T. (2017, 22. desember). «Pora zabrat Frude domoj!». Novaja Gazeta. https://novayagazeta.ru/ articles/2017/12/22/75019-pora-zabrat-frude-domoy.

Cepurītis, M., Juurvee, I., Keišs, A., Marnot, D., Ruston, S., \& Carrasco Rodríguez, B. (2021). Russia's footprint in the Nordic-Baltic information environment. (Rapport 2019/2020). NATO StratCom COE.

colonelcassad. (2018a, 13. mars). Norvezjskij spits na amerikanskom povodke. Colonel Cassad: Rupor totalitarnoj propagandy. https://colonelcassad.livejournal.com/4048019.html

colonelcassad. (2018b, 23. april). Proverennye metody k 100-letiju VChK. Colonel Cassad: Rupor totalitarnoj propagandy. https://colonelcassad.livejournal.com/4141648.html

colonelcassad. (2018c, 2. mai). Sjpionskie igry v Kirkenese. Colonel Cassad: Rupor totalitarnoj propagandy. https://colonelcassad.livejournal.com/4161862.html

colonelcassad. (2018d, 15. mars). TSRU i partnery. Colonel Cassad: Rupor totalitarnoj propagandy. https:// colonelcassad.livejournal.com/4052423.html

Datatilsynet. (2019). Vurdering av personvernkonsekvenser (DPIA). https://www.datatilsynet.no/rettigheter-ogplikter/virksomhetenes-plikter/vurdere-personvernkonsekvenser/vurdering-av-personvernkonsekvenser/

De Seta, G. (2020). Three lies of digital ethnography. Fournal of Digital Social Research, 2(1), 77-97.

Deloitte. (2020). Mediapotreblenie v Rossii - 2020. Deloitte. https://www2.deloitte.com/content/dam/Deloitte/ $\mathrm{ru} /$ Documents/technology-media-telecommunications/russian/media-consumption-russia-2020.pdf

Den nasjonale forskningsetiske komité for samfunnsvitenskap og humaniora (NESH). (2019). Forskningsetisk veileder for internettforskning. https://www.forskningsetikk.no/retningslinjer/hum-sam/forskningsetiskveileder-for-internettforskning/

Denisova, A. (2017). Democracy, protest and public sphere in Russia after the 2011-2012 anti-government protests: Digital media at stake. Media, Culture E Society, 39(7), 976-994.

Deverell, E., Wagnsson, C. \& Olsson, E.-K. (2021). Destruct, direct and suppress: Sputnik narratives on the Nordic countries. The fournal of International Communication, 27(1), 15-37.

Diesen, S. (2018). Lavintensivt hybridangrep på Norge i en fremtidig konflikt. Forsvarets forskningsinstitutt.

Etling, B., Roberts, H. \& Faris, R. (2014). Blogs as an alternative public sphere:The role of blogs, mainstream media, and TV in Russia's media ecology. Berkman Center Research Publication.

EUvsDisinfo. (2019, 9. november). Disinfo: In Ukraine, pensioners freeze without Russian gas. https:// euvsdisinfo.eu/report/in-ukraine-pensioners-freeze-without-russian-gas/

Fredheim, R. (2017). Robotrolling 1/2017. NATO StratCom COE.

Fredheim, R. \& Van Sant, K. (2020). Robotrolling 3/2020. NATO StratCom COE. 
Garmazjapova, A. (2013, 7. september). Gde zjivut trolli. I kto ikh kormit. Novaja Gazeta. https://novayagazeta. ru/articles/2013/09/07/56253-gde-zhivut-trolli-i-kto-ih-kormit?print=true

Gerhardsen, A. (2019, 26. desember). Medierevisjonen: Frode Berg-syndromet. Aftenposten. https://www. aftenposten.no/meninger/debatt/i/LABkzR/medierevisjonen-frode-berg-syndromet-anki-gerhardsen

Godzimirski, J. M. \& Sergunin, A. (2020). Russian expert and official geopolitical narratives on the Arctic: Decoding topical and paradigmatic DNA. Arctic Review on Law and Politics, 11, 22-46.

Golovchenko, Y. (2020). Measuring the scope of pro-Kremlin disinformation on twitter. Humanities and Social Sciences Communications, 7(1), 1-11.

Helmus, T. C., Bodine-Baron, E., Radin, A., Magnuson, M., Mendelsohn, J., Marcellino, W., Bega, A. \&Winkelman, Z. (2018). Russian socialmedia influence: Understanding Russian propaganda in Eastern Europe. Rand Corporation.

Human Rights Watch. (2020). Russia: Growing internet isolation, control, censorship. Human Rights Watch. https:// www.hrw.org/news/2020/06/18/russia-growing-internet-isolation-control-censorship

InoTV. (2014, 12. desember). Bloomberg: Rossija pokhozja na Mordor, a ukraintsy - na khobbitov. InoTV / Bloomberg. https://russian.rt.com/inotv/2014-12-12/Bloomberg-Rossiya-pohozha-na-Mordor

InoTV. (2018a, 5. februar). WP: Sjpionskij skandal s norvezjskim pensionerom uglubit raskol mezjdu Moskvoi i Zapadom. InoTV / Washington Post. https://russian.rt.com/inotv/2018-02-05/WP-shpionskij-skandal-snorvezhskim

InoTV. (2018b, 23. april). Yle: Norvezjskij pensioner priznal vinu v sjpionazje protiv Rossii. InoTV/Yle. https:// russian.rt.com/inotv/2018-04-23/Yle-norvezhskij-pensioner-priznal-vinu

InoTV. (2019a, 13. august). Daily Telegraph rasskazala, kak «sonnyj» norvezjskiv gorodok stal arenoi sjpionskoj vojny Moskvy i Oslo. InoTV / Daily Telegraph. https://russian.rt.com/inotv/2019-08-13/Daily-Telegraphrasskazala-kak-sonnij

InoTV. (2019b, 21. november). Euronews: Zjiteli norvezjskogo Kirkenesa ne khotjat sjpionti za Rossiej. Euronezws / InoTV. https://russian.rt.com/inotv/2019-11-21/Euronews-zhiteli-norvezhskogo-Kirkenesa-ne

InoTV. (u.å.). O sajte. https://russian.rt.com/inotv/about

Interfax. (2015, 20. mai). V Rossii pojmali litovskogo sjpiona. Interfax. https://www.interfax.ru/russia/442698

Interfax. (2016, 13. mai). FSB objavila o zaderzjanii v Peterburge estonskogo sjpiona. Interfaks. https://www. interfax.ru/russia/508170

Kalsaas, J. (2020). Battle for the North: Russian cyberconflict over commemorating the Red Army's liberation of Northern Norway. I Anisimova, I. \& Lunde, I. (Red.), The cultural is political: Intersections of Russian art and state politics (s. 128-154). Slavica Bergensia.

Koenitz, H., Ferri, G., Haahr, M., Sezen, D. \& Sezen, T. İ. (2015). Introduction: Perspectives on interactive digital narrative. I H. Koenitz, G. Ferri, M. Haahr, D. Sezen \& T. İ. Sezen (Red.), Interactive digital narrative (s. 1-8). Routledge.

Kolozaridi, P. \& Dovbysh, O. (2020). Diversity of the internet in Russia's regions: Towards an alternative research agenda. I Internet in Russia (s. 149-169). Springer.

Korotkov, D. (2018, 5. november). Povar so svoimi tarakanami. Novaja Gazeta. https://novayagazeta.ru/ articles/2018/11/08/78496-provokatsii-prigozhina

Kurowska, X. \& Reshetnikov, A. (2018). Neutrollization: Industrialized trolling as a pro-Kremlin strategy of desecuritization. Security Dialogue, 49(5), 345-363.

Käpylä, J. \& Mikkola, H. (2015). On Arctic exceptionalism. Critical reflections in the light of the Arctic sunrise case and the crisis in Ukraine. Helsinki: The Finnish Institute of International Affairs (Working paper 85), 1-22.

Lavrov, S. (2019, 23. oktober). Russland og Norge: felles fortid og pragmatisk fremtid Aftenposten. https://www. aftenposten.no/meninger/debatt/i/QoK65R/russland-og-norge-felles-fortid-og-pragmatisk-fremtidsergey-lavrov

Linvill, D. L. \& Warren, P. L. (2019, 8. mars). Russian trolls have mastered the viral tweet. Washington Post. https:/www.washingtonpost.com/outlook/russian-trolls-can-be-surprisingly-subtle-and-often-fun-to$\mathrm{read} / 2019 / 03 / 08 / 677 f 8 e c 2-413 \mathrm{c}-11 \mathrm{e} 9-9361-301 \mathrm{ffb} 5 \mathrm{bd5e6}$ _story.html

Lusberg, M. \& Sørenes, K. M. (2018, 3. mars). Massiv norsk spionasje. Klassekampen. https://arkiv. klassekampen.no/article/20180303/ARTICLE/180309988

Marcus, G. E. (1995). Ethnography in/of the world system: The emergence of multi-sited ethnography. Annual Review of Anthropology, 24(1), 95-117.

Maréchal, N. (2017). Networked authoritarianism and the geopolitics of information: Understanding Russian internet policy. Media and Communication, 5(1), 29-41.

Markham, A. (2020). Doing digital ethnography in the digital age. (Working paper). https://doi.org/10.31235/ osf.io/hqm $4 \mathrm{~g}$ 
Merkatsjeva, E. (2013, 17. november). Tajny trollinga: Kak nanimajut virtualnykh killerov dlja polititsjeskikh ubijstv. Moskovskij Komsomolets. https:/www.mk.ru/social/article/2013/11/17/946434-taynyi-trollingakak-nanimayut-virtualnyih-killerov-dlya-politicheskih-ubiystv.html\#loaded-37

Novaja Gazeta. (2019). Norvezjskij pensioner Frode Berg otsjen ljubil Rossiju i russkuju kulturu (...). Odnoklassniki. https://ok.ru/novayagazeta/topic/70211603540806

Oliveira de Almeida Toscano, L. (2019). Kirkenes: A case for borderland Norwegians? An analysis of the discourses and practices towards Russia following the Storskog and Frode Berg cases [Masteroppgave, Universitetet i Oslo]. DUO vitenarkiv. http://urn.nb.no/URN:NBN:no-76347.

Page, R., Harper, R. \& Frobenius, M. (2013). From small stories to networked narrative: The evolution of personal narratives in Facebook status updates. Narrative Inquiry, 23(1), 192-213.

Politiets sikkerhetstjeneste. (2021). Nasjonal trusselvurdering 2021. https://www.pst.no/alle-artikler/trusselvur deringer/nasjonal-trusselvurdering-2021/

Potsjeptsov, G. (2021). Fabriki mnenij: Trolli i telepropagandisty v odnoj uprjazjke na borbe s massovym soznaniem. Akademïa Ukrainskoi Presi. https:/www.aup.com.ua/fabriki-mneniy-trolli-i-telepropagan/

Presidenten for Den russiske føderasjon. (2020). Ukaz prezidenta Rossijskoj Federatsii: O Strategii razvitija Arktitsjeskoj zony Rossijskoj Federatsii i obespetsjenija natsionalnoj bezopasnosti na period do 2035 goda.

Rid, T. (2020). Active measures: The secret history of disinformation and political warfare. Farrar, Straus and Giroux.

Rogers, J. \& Tyushka, A. (2017). "Hacking» into the West: Russia's «anti-hegemonic» drive and the strategic narrative offensive. NATO StratCom COE.

Rowe, L. (2019). Lite nytt om Frode Berg. Nordisk Østforum, 33, 69-71.

Rusajeva, P. \& Zakharov, A. (2017, 17. oktober). Rassledovanije RBK: kak «fabrika trollej» porabotala na vyborakh SSjA. RBC. https://www.rbc.ru/magazine/2017/11/59e0c17d9a79470e05a9e6c1

Ruxpert. (2020). Prorossijskie blogery, soobsjtsjestva i SMI. https://ruxpert.ru/Пророссийские_блогеры, сообщества_и_СМИ

Sadler, N. (2017). Narrative and interpretation on Twitter: Reading tweets by telling stories. New Media $\mathcal{G}$ Society, 20(9), 3266-3282.

Sanovich, S. (2017). Computational propaganda in Russia:The origins of digital misinformation. Computational Propaganda Research Project:Working paper 2017.3.

Starbird, K. (2019). Disinformation's spread: Bots, trolls and all of us. Nature, 571(7766), 449.

Starbird, K., Arif, A. \& Wilson, T. (2019). Disinformation as collaborative work: Surfacing the participatory nature of strategic information operations. Proceedings of the ACM on Human-Computer Interaction, 3 (CSCW), 1-26.

Strand, O. M. \& Hagen, J. M. (2015). Med propagandaens århundre unnagjort - hva er propagandatrusselen mot et digitalisert Norge? Forsvarets forskningsinstitutt.

Stukal, D., Sanovich, S., Bonneau, R. \& Tucker, J. A. (2017). Detecting bots on Russian political Twitter. Big data, 5(4), 310-324.

Svazovskij, S. (2018, 21. november). «ES i kruzjevnye trusiki»: Za sjto "stojal Majdan», i sjto polutsjila Ukraina pjat let spustja. FAN. https://riafan.ru/1123384-es-i-kruzhevnye-trusiki-za-chto-stoyal-maidan-i-chtopoluchila-ukraina-pyat-let-spustya

Sylvia IV, J. (2020). From Livejournal with love: A comparative analysis of Russia's domestic and international disinformation campaigns. SocArXiv.

TASS. (2019, 26. oktober). Lavrov prizval Norvegiiu sodeistvovat normalizatsii dialoga mezjdu Rossijei $i$ NATO. TASS. https://tass.ru/politika/7048165

Van Duijn, S. (2020). Everywhere and nowhere at once: The challenges of following in multi-sited ethnography. fournal of Organizational Ethnography, 9(3), 281-294.

Vesselkov, A., Finley, B. \& Vankka, J. (2020). Russian trolls speaking Russian: Regional Twitter operations and MH17. 12th ACM Conference on Web Science, 86-95.

Vikirealnost. (2021, 2. mai). Kolonel Kassad. http://wikireality.ru/wiki/Colonel_Cassad

Voltsjek, D. (2021, 24. januar). «Nasja norma - 120 kommentov v den». Zjizn kremlevskogo trollja. Radio Svoboda. https://www.svoboda.org/a/31065181.html

Wagnsson, C. \& Barzanje, C. (2019). A framework for analysing antagonistic narrative strategies: A Russian tale of Swedish decline. Media, War E Conflict, 14(2), 239-257.

Walker, J. (2004). Distributed narrative: Telling stories across networks. Internet Research Annual, 3, 91-104.

Walker, S. (2015, 2. april). The Russian troll factory at the heart of the meddling allegations. The Guardian. https:/www.theguardian.com/world/2015/apr/02/putin-kremlin-inside-russian-troll-house

Wilhelmsen, J. M. \& Gjerde, K. L. (2018). How the new cold war travelled north (part I): Norwegian and Russian narratives. NUPI. 
Yablokov, I., \& Chatterje-Doody, P. N. (2021). Russia Today and conspiracy theories: People, power and politics on $R T$. Routledge.

Zakharov, A. \& Rusjaeva, P. (2017). Rassledovanie RBK: kak iz «fabriki trollej» vyrosla «fabrika media». $R B C$. https://www.rbc.ru/magazine/2017/04/58d106b09a794710fa8934ac

Zakharova, M. (2017). Brifing ofitsialnogo predstavitelja MID Rossii M. V. Zakharovoj, Moskva, 28.12.2017. https://www.mid.ru/web/guest/ukraine/-/asset_publisher/HfLxJk5I2xvu/content/id/3012378\#23

Zakharova, M. (2020). Brifing ofitsialnogo predstavitelja MID Rossii M. V. Zakharovoj, Moskva, 19.11.2020. https://www.mid.ru/ru/press_service/spokesman/briefings/-/asset_publisher/D2wHaWMCU6Od/content/ $\mathrm{id} / 4443750 \# 30$

Zannettou, S., Caulfield, T., Setzer, W., Sirivianos, M., Stringhini, G. \& Blackburn, J. (2019). Who let the trolls out? Towards understanding state-sponsored trolls. Proceedings of the 10th acm conference on web science (s. 353-362).

Zvereva, V. (2020). Trolling as a digital literary practice in the Russian language internet. Russian Literature, $118,107-140$.

Østbø, J. (2021). I grenseland. Historien om Frode Berg og livet på innsiden av norsk etterretning og russiske fengsler. Nordisk Østforum, 35. https://doi.org/10.23865/noros.v35.2847 